\title{
PENGARUH MEDIA AUDIO VISUAL TERHADAP PENGUASAANKOSAKATA (KATA KERJA DAN KATA BENDA) ANAK KELOMPOK B2 RA ALHASANIYAH NW JENGGIK
}

\author{
Najamuddin ${ }^{1}$ Hidayaturrahman ${ }^{2}$ \\ E-mail : najamuddinfarabi@gmail.com \\ E-mail : hidayaturrahman1113@gmail.com \\ $\underline{\text { Pendidikan guru pendidikan anak usia dini, universitas hamzanwadi }}$
}

\begin{abstract}
Abstrak
Penelitian ini bertujuan untuk mengetahui Pengaruh Media Audio Visual Terhadap Penguasaan Kosakata (Kata Kerja Dan Kata Benda) Anak Kelompok B2 Ra Alhasaniyah NW Jenggik Tahun Ajaran 2017/2018. Jenis peneltian ini adalah penelitian eksperimen, dengan bentuk desain one-group pretest-posttest design.. Populasi penelitian ini adalah kelompok B1 dan B2 RA Al Hasaniyah NW Jenggik Tahun Ajaran 2017/2018 . Sampel penelitian meliputi kelompok B2 yang terdiri dari 15 anak. Instrumen penelitian yang digunakan dalam penelitian berupa lembar observasi dan tes. Tes dalam bentuk lembar kerja siswa yang terdiri atas 15 butir soal. Teknik analisa data menggunakan uji normalitas, dan uji hipotesis menggunakan uji-t. Hasil pengujian normalitas kelas eksperimen pretest yaitu 8,65 dan postest yaitu 9,50 dengan $\mathrm{X}^{2}$ tabel 11,070, maka data hasil belajar anak berdistribusi normal dan dilihat dari rata-rata nilai akhir tes yaitu dari 57,6 menjadi 66,66, maka ada peningkatan hasil belajar anak, selain itu juga terlihat pada hasil perhitungan pengujian hipotesis yang menunjukan bahwa $t_{\text {hitung }}(2,226)>t_{\text {tabel }}(2,131)$. Dimana $t_{\text {tabel }}$ dihitung dengan taraf kepercayaan $5 \%$ adalah 2,131. Jadi, hasil pengujian hipotesis adalah signifikan, maka Ho ditolak dan $\mathrm{Ha}$ diterima. Sehingga dari hasil uji data tersebut dapat disimpulkan bahwa media audio visual berpengaruh terhadap penguasaan kosakata (kata kerja dan benda) anak Kelompok B2 Ra Alhasaniyah NW Jenggik Tahun Ajaran 2017/2018
\end{abstract}

Kata Kunci : Media Audio Visual, Penguasaan Kosakata (Kata Kerja Dan Kata Benda).

PENDAHULUAN 
Pendidikan Anak Usia Dini merupakan suatu upaya pembinaan yang ditujukan kepada anak sejak lahir sampai usia 6 (enam) tahun yang dilakukan melalui pemberian rangsangan pendidikan untuk membantu pertumbuhan dan perkembangan jasmani dan rohani agar anak memiliki kesiapan dalam memasuki pendidikan lebih lanjut.

Pertumbuhan dan perkembangan pada anak usia dini merupakan periode yang sangat penting karena pada masa ini pertumbuhan dasar yang akan mempengaruhi dan menentukan perkembangan anak selanjutnya. Perkembangan pada usia dini meliputi perkembangan kemampuan berbahasa, kreatifitas kesadaran sosial, emosional dan intelegensi berjalan sangat cepat dan merupakan landasan perkembangan berikutnya. Perkembangan moral serta dasar-dasar kepribadian juga dibentuk pada masa tersebut. Perkembangan ini terdapat masa kritis, dimana diperlukan rangsangan/stimulasi yang berguna agar potensi berkembang.

Manusia dalam kehidupannya tidak terlepas dari bahasa. Ia harus mampu menggunakan bahasa sebagai alat komunikasi. Dengan bahasa, mereka akan mudah dalam bergaul dan mudah menyesuaikan diri dengan lingkungannya. Bahasa mempunyai peranan yang sangat penting bagi kehidupan manusia.

Bahasa sebagai alat komunikasi, merupakan sarana yang sangat penting dalam kehidupan anak. Minat anak pada usia dini sangat luas dan mereka selalu ingin mengetahui segala sesuatu yang ada disekitarnya. Anak adalah makhluk peniru (imitator), anak mencontoh orang-orang yang ada di sekelilingnya ketika melihat sesuatu yang baru dilihat oleh anak karena pada masa ini anak-anak memiliki rasa tahu yang tinggi dan dorongan untuk meniru orang lain sangat kuat. Kemampuan imitasi anak menjadi modal penting dalam perkembangan bahasanya.

Perkembangan bahasa anak sejalan dengan rasa ingin tahu serta sikap antusias yang tinggi, sehingga timbul pertanyaan-pertanyaan dari anak dengan kemampuan bahasanya. Perkembangan bahasa anak antara usia 4 dan 5 tahun, kalimat anak sudah terdiri dari empat sampai lima kata. Perkembangan bahasa anak antara usia 5 dan 6 tahun, kalimat anak sudah terdiri dari enam sampai delapan kata. Mereka sudah dapat menjelaskan arti kata-kata yang sederhana (Wahyudi dkk, 2011: 38). 
Pada dasarnya pemahaman kosakata merupakan salah satu komponen pembelajaran bahasa. Kosakata atau pembendaharaan kata sangatlah penting dimiliki oleh anak-anak. Dengan penjelasan sebelumnya, dapat diketahui bahwa kosakata pada anak sangatlah penting karena bahasa itu sendiri merupakan alat untuk berkomunikasi. Pada anak usia dini pengembangan bahasa sangatlah penting, karena pada masa usia dini merupakan masa peka bagi anak.

Berdasarkan pengamatan yang dilakukan oleh peneliti di kelompok B2 RA A1Hasniyah NW Jenggik, ditemukan masalah yang terjadi yang Pertama, metode yang digunakan dalam pembelajaran masih konversional, kedua perbendaharaan kosakata (kata kerja dan kata benda) yang dimiliki anak masih kurang, Ketiga, dalam pembelajaran guru masih menggunakan teknik menirukan secara lisan dengan tidak menggunakan media sehingga anak-anak kurang mengingat kosakata yang telah disampaikan dan pembelajaran yang kurang menarik membuat anak cepat bosan.

Berdasarkan Permasalahan-permasalahan diatas maka rumusan masalah dalam penelitian ini adalah apakah ada pengaruh media audio visual terhadap penguasaan kosakata (kata kerja dan kata benda) anak kelompok B2 RA Al-Hasniyah NW Jenggik?

Adapun tujuan dalam penelitian ini adalah untuk mengetahui pengaruh media audio visual terhadap penguasaan kosakata (kata kerja dan benda) anak kelompok B2 RA AL Hasaniyah NW Jenggik Tahun Ajaran 2017/2018. 


\section{METODE PENELITIAN}

Metode yang digunakan dalam penelitian ini adalah metode eksperimen, dalam metode eksperimen ini ada perlakuan (treatment). Dalam melakukan penelitian tentunya banyak metode yang dapat digunakan, salah satunya dengan metode eksperimen. Metode eksperimen merupakan bagian dari metode kuantitatif yang mempunyai ciri khas tersendiri.

Menurut Sugiyono (2014: 72) bahwa "Metode penelitian eksperimen dapat diartikan sebagai metode penelitian yang digunakan untuk mencari pengaruh perlakuan tertentu terhadap yang lain dalam kondisi yang terkendalikan”.

Menurut Sugiyono (2014 : 74 ) desain penelitan merupakan suatu bentuk gambaran untuk mempermudah langkah-langkah pemecahan masalah atau pengujian hipotesis. Desain penelitian yang akan digunakan dalam penelitian ini adalah one-group pretest-posttest design. Dalam desain penelitian ini terdapat pretest sebelum diberikan perlakuan. Dengan demikian hasil perlakuan dapat diketahui lebih akurat, karena dapat membandingkan dengan keadaan sebelum diberi perlakuan. Desain ini dapat digambarkan seperti berikut:

\section{$\mathrm{O}_{1} \mathrm{X} \mathrm{O}_{2}$}

Desain Penelitian

Keterangan :

$\mathrm{O}_{1} \quad$ : Pretest

X : Perlakuan

$\mathrm{O}_{2} \quad$ : Posttest

Pada desain penelitian di atas, peneliti memberikan pretest dan posttest untuk mengetahui keadaan awal dan akhir penelitian Sejauh mana tingkat hasil belajar siswa tentang penguasaan kosa kata (kata kerja dan kata benda) anak. 


\section{HASIL PENELITIAN DAN PEMBAHASAN}

Data dalam penelitian ini diperoleh dengan memberikan tes kepada siswa dalam bentuk lembar kerja siswa yang diberikan sebelum proses kegiatan belajar berlangsung yang disebut dengan pre-test dan sesudah proses kegiatan belajar berlangsung yang disebut dengan post-test, dan menggunakan lembar observasi untuk menguatkan hasil dari tes yang diberikan pada kelas eksperimen pada tema lingkungan sekolah dengan sub-sub tema (alat alat sekolah) untuk mengetahui sejauh mana tingkat hasil belajar anak.

Tes yang diberikan kepada anak dalam bentuk lembar kerja siswa yang berjumlah 15 butir soal serta melakukan pengamatan kepada anak dengan menggunakan lembar observasi yang berjumlah 10 butir pernyataan. Data observasi dihitung dengan menggunakan skala likert dengan penskoran 1 sampai 5 dan penilaian tes menggunakan rumus korelsi product moment. Dari data observasi yang sudah terkumpul diperoleh katagori penilaian pre-test cukup baik, sebaliknya pada post-test meningkat menjadi baik, dalam penguasaan kosakata (kata kerja dan kata benda) anak kelompok B2 RA A1Hasaniyah NW Jenggik Tahun Ajaran 2017/2018.

Diskripsi nilai observasi pre-test dan post-test observasi disajikan di tabel 4.1

Tabel 4.1.

Rata-Rata Nilai Pre-test dan Pos-ttest Observasi.

\begin{tabular}{|l|l|l|l|l|}
\hline Kelas & Pretest & Keterangan & posttest & $\begin{array}{l}\text { Keteranga } \\
\mathrm{n}\end{array}$ \\
\hline $\begin{array}{l}\text { Eksperi } \\
\text { men }\end{array}$ & $25,98<\mathrm{X} \leq 34,02$ & Cukup baik & $34,02<\mathrm{X} \leq 42,06$ & Baik \\
\hline
\end{tabular}

Adapun dilihat dari hasil tes anak diperoleh skor terendah dari hasil pretest adalah 47 dan skor tertinggi adalah 73. Sedangkan skor terendah dari hasil postest adalah 53 dan skor tertinggi adalah 87 , sehingga dari perhitungan yang dilakukan terhadap data 
tersebut didapat nilai rata-rata dari hasil pretest adalah 57,6 dan hasil postest diperoleh nilai rata-ratanya adalah 66,66 . Deskripsi nilai pre-test dan post-test kelas eksperimen disajikan pada tabel 4.2 .

Tabel 4.2.

Rata-RataNilai Pre-test dan Pos-ttest

\begin{tabular}{|l|c|c|}
\hline \multirow{2}{*}{ Kelas } & \multicolumn{2}{|c|}{ Rata-Rata } \\
\cline { 2 - 3 } & Pre-test & Post-test \\
\hline Eksperimen & 57,6 & 66,66 \\
\hline
\end{tabular}

Dari tabel diketahui bahwa terdapat perbedaan nilai rata-rata yang diperoleholeh siswa sebelum dan setelah proses belajar mengajar berlangsung.Pada kelas eksperimen nilai rata-rata pre-testsebesar 57,6 dan pada post-test diperoleh kenaikan nilai rata-rata sebesar 66,66. Data pre-test dan post-test menggambarkan bahwa ada peningkatan hasil belajar anak setelah menggunakan media audio visual terhadap penguasaan kosakata (kata kerja dan benda) anak kelompok B2 RA Alhasiyah NW Jenggik tahun pembelajaran 2017/2018.

\section{Hasil Uji Normalitas}

Tabel 4.4

Hasil Uji Normalitas Data

\begin{tabular}{|c|c|c|c|c|}
\hline \multirow{2}{*}{ Kelas } & \multicolumn{2}{|c|}{$\mathrm{X}^{2}$ hitung } & \multirow{2}{*}{$\mathrm{X}^{2}$ tabel } & \multirow{2}{*}{ Keterangan } \\
\cline { 2 - 4 } & Pre-test & Post-test & & \\
\hline Eksperimen & 8,65 & 9,50 & 11,070 & Distribusi Normal \\
\hline
\end{tabular}

Setelah dilakukan perhitungan data dari hasil pre-test dan post-test siswa kelas eksperimen diperoleh $\mathrm{X}^{2}$ hitung hasil pre-test dan post-test sebesar 8,65 dan 9,50 
kemudian dicocokkan dengan harga $\mathrm{X}^{2}$ tabel sebesar 11,070. Sehingga dapat disimpulkan bahwa data pre-test dan post-test siswa tersebut berdistribusi normal.

\section{UJI HIPOTESIS}

Setelah uji pra syarat dilakukan, maka uji berikutnya adalah uji hipotesis penelitian. Uji hipotesis dilakukan untuk melihat apakah ada pengaruh media audio visual terhadap penguasaan kosakata (kata kerja dan kata benda) anak. Adapun langkah-langkah untuk analisis uji hipotesis (uji-t) adalah sebagai berikut:

$$
\begin{aligned}
& \mathrm{t}=\frac{\bar{y}-x}{\sqrt{\frac{\sum D^{2}-\left(\sum D\right)^{2}: N}{N(N-1)}}} \quad \mathrm{t}=\frac{9,06}{\sqrt{\frac{3485}{210}}}=\frac{5,04}{\sqrt{5,65}} \\
& \mathrm{t}=\frac{66,66-57,6}{\sqrt{\frac{4802-(136)^{2}: 15}{15(15-1)}}} \quad \mathrm{t}=\frac{9,06}{4,07}=2,226 \\
& \mathrm{t}=\frac{9,06}{\sqrt{\frac{4718-1233}{15(14)}}}
\end{aligned}
$$

Hasil t-tabel dengan $\mathrm{N}-1=15-1=14$, dengan taraf kepercayaan $5 \%$ adalah 2,131. Hasil t-hitung dibandingkan dengan t-tabel yaitu t-hitung $(2,226)>\mathrm{t}$-tabel $(2,131)$. Dengan demikian maka Ho ditolak dan Ha diterima. Sehingga, pembelajaran dengan media audio visual berpengaruh positif terhadap penguasaan kosakata (kata kerja dan kata benda) anak kelompok B2 RA Al Hasaniyah NW Jenggik Ajaran $2017 / 2018$.

Dari hasil penelitian dan pembahasan yang dikemukakan di atas, maka peneliti dapat menarik kesimpulan bahwa media audio visual berpengaruh terhadap penguasaan kosakata (kata kerja dan benda) anak kelompok B2 RA Al Hasaniyah NW Jenggik Tahun Ajaran 2017/2018. Hal ini terlihat dari rata-rata nilai akhir baik itu dilihat dari hasil pengamatan (observasi), nilai tes, dan pengujian normalitas, selain itu juga terlihat pada hasil perhitungan pengujian hipotesis dengan uji t. 
Sesuai dengan hasil analisis data yang berhasil dikumpulkan dalam penelitian ini sebagai berikut:

1. Hasil pengamatan (observasi) diperoleh dari hasil pretest adalah $17,94<\mathrm{X} \leq 25,98$ (kurang baik), 25,98 $<\mathrm{X} \leq 34,02$ (cukup baik) dan posttest menjadi 25,98<X $\leq$ 34,02 (cukup baik), 34,02 $<\mathrm{X} \leq 42,06$ (baik).

2. Hasil nilai tes pada pretest yaitu 57,6 dan posttest 66,66 , maka data hasil belajar siswa mengalami peningkatan.

3. Hasil uji normalitas pada pretest dan posttest dengan menggunakan rumus chi kuadrat, $X^{2}{ }_{\text {hitung }}<X^{2}$ tabel, hasil pretestnya yaitu 8,65 dan untuk posttestnya 9,50, dengan $\mathrm{X}^{2}$ tabel sebesar 11,070, maka data hasil belajar siswa dari pretest dan posttest berdistribusi normal.

4. Hasil pengujian hipotesis diperoleh $t_{\text {hitung }}(2,226)>t_{\text {tabel }}(2,131)$. Dimana $t_{\text {tabel }}$ dihitung dengan taraf kepercayaan 5\% adalah 2,131.hal ini berarti $t_{\text {hitung }}>t_{\text {tabel }}$ atau $2,226>2,13$. Jadi, hasil pengujian hipotesis adalah signifikan (diterima), maka Ho ditolak dan Ha diterima. Sehingga hipotesisnya berbunyi “ terdapat pengaruh media audio visual terhadap penguasaan kosakata (kata kerja dan benda) anak kelompok B2 RA Al Hasaniyah NW Jenggik Tahun Ajaran 2017/2018.

\section{DAFTAR PUSTAKA}

Sugiyono. 2014. Meode Penelitian Kuantitatif Kualitatif Dan $R$ \& D. Bandung: Alfabeta Bandung.

Wahyudi, Uyu Dan M. Agustin. (2011). Penilaian Perkembangan Anak Usia Dini. Bandung: Pt. Refika Aditama. 